\title{
MAFRA, J. J. CULTURA CLÁSSICA GREGA E LATINA. BELO HORIZONTE: PUC MINAS, 2010 (211 p.) ISBN: 8560778543
}

\author{
Priscilla Adriane Ferreira Almeida $\star$ \\ Universidade Federal de Minas Gerais
}

ultura clássica grega e latina se propõe a tratar de alguns temas da literatura greco-romana, como a épica, a fábula, o conto; e ainda esclarecer sobre aspectos da comédia e da tragédia, entre outras discussões. Foi escrita por Johnny José Mafra, atualmente professor de língua latina, metodologia da pesquisa linguística e literária e literatura clássica nos cursos da Pontifícia Universidade Católica de Minas Gerais.

Em muitos dos capítulos da obra, Mafra inicia o assunto pela etimologia para depois oferecer sua definição. A seguir, coloca a evolução dos termos durante os anos e apresenta várias concepções acerca dos mesmos para outros estudiosos.

No primeiro capítulo desse livro, Sobre clássico e autor clássico, não poderia ser diferente. O que torna uma obra clássica? Em que consiste um clássico, a sua essência? A partir destes questionamentos, Mafra disseca o conceito de "clássico". Primeiramente, ele explica o que o termo clássico significava em latim (clássico como sendo um elemento elevado, de prestígio) e como foi evoluindo ao longo dos séculos. Ao contrário do que muitos imaginam, nem todas as obras da Antiguidade eram consideradas clássicas, mas apenas os autores que se apresentavam como prototípicos pela criação e pela linguagem, pelo seu caráter formador e transformador do homem (p. 17). Nos séculos XVII e XVIII, o conceito era usado para definir o que era lido e estudado nas escolas. Posteriormente, o termo clássico adquiriu outro sentido: passou a

^prisadriane@gmail.com 
designar uma obra cujo modelo artístico é greco-romano, com gosto pelas regras, perfeição e simplicidade das estruturas artísticas. Já Mafra considera como clássica uma obra a partir da qual se definem novos cânones da estética literária, e que se torna um modelo para as novas gerações.

Em cada um dos capítulos, Mafra, sistematicamente, coloca trechos das obras relacionadas ao tema. No capítulo sobre conto e fábula, por exemplo, ele explica a estrutura didática desses gêneros e esclarece como estas formas narrativas se relacionam com a educação do homem grego (a paideia). Para ilustrar o tema, ele cita três exemplos da poesia didática de Hesíodo: o mito de Pandora, o mito das cinco Idades e a fábula do gavião e o rouxinol. Ele ainda transcreve uma fábula de Horácio e outra de Fedro, primeiramente com o texto original em latim e a seguir com a tradução, feita por ele próprio, em português.

Mafra ainda trata, em um longo capítulo, do gênero trágico. No capítulo Hýbris: a essência da tragédia, ele começa por explicar o termo tragédia, buscado em acepções de vários dicionários diferentes e de épocas distintas. Mafra se propõe a apresentar a tragédia do ponto de vista de uma estrutura dramática que representa ações importantes de personagens ilustres, levando em consideração o que interfere na vida do homem e determina a sua tragicidade.

$\mathrm{O}$ autor realça que a essência da tragédia consiste no conflito entre o homem, ser inteligente e dono de vontade, e a força cega da natureza (p. 71 e 72). A seguir, ele enumera os elementos do trágico: a hamartía, falha trágica (segundo Aristóteles); hýbris, o excesso, a desmedida; moîra, o destino ou fatalidade; a catarse, a purgação, que é realizada através da piedade e do terror que a tragédia inspira em seus espectadores.

Após tratar destes temas de origem grega, no capítulo seguinte o classicista explica sobre a tradição poética na Itália, ampliando suas reflexões para discorrer também sobre a história do surgimento e formação do povo romano e de sua literatura.

No capítulo posterior, Tópicos para leitura e conhecimento da epopeia latina, o autor remonta ao surgimento da epopeia grega e de seu forte caráter oral, fazendo um pequeno resumo do enredo da Ilíada e da Odisseia. Ele também enumera as características de aedos e rapsodos, percorrendo o tema dos primórdios até o período helenístico. A seguir, trata das origens da epopeia latina, a partir da tradução da Odisseia feita por Lívio Andronico, no século III a.C. e também cita outros autores da época arcaica romana, como Névio e Ênio. 
Após este capítulo, a obra retoma o escopo da tragédia, mas agora no contexto romano, com Sêneca, particularizando, com estudo cuidadoso, a tragédia Édipo. Num viés histórico o autor aborda o surgimento da tragédia em Roma, também pelas mãos de Lívio Andronico, o seu desenvolvimento e decadência, já no século I d.C. Mafra também descreve a tragédia Édipo, do grego Sófocles, tratando do mito de Édipo desde suas origens e explicitando como esse mito foi usado posteriormente, em autores como Voltaire e Hölderlin, entre outros.

Após estudar a tragédia, o autor passa a esclarecer sobre a comédia, o seu surgimento em rituais em honra ao deus Dioniso e sua fase primitiva na Grécia, definida como "Comédia Antiga", cujo marco final é o famoso Aristófanes, do século IV a.C. Ele também elucida sobre as fases da "Comédia Média" e da "Comédia Nova", e teoriza sobre o modo como esta última influenciou a comédia em Roma.

Novamente, Mafra volta a tratar da épica, desta vez a latina, no capítulo sonho, mito e realidade, que consiste numa conferência que ele proferiu no simpósio do bimilésimo aniversário de morte de Virgílio, realizado em 1981, na Academia Brasileira de Letras, no Rio de Janeiro. Nesse capítulo, ele faz uma detalhada análise do livro VIII da Eneida e do mito de Eneias.

No capítulo seguinte, baseado em um ensaio escrito em 1984 e publicado no periódico Ensaios de Semiótica, da Faculdade de Letras da Universidade Federal de Minas Gerais, Mafra esclarece mais sobre o livro VI da Eneida. Apesar da análise acurada, nesse capítulo algumas citações do texto no original em latim e a tradução para o português, elaborada por ele, parecem ter algo de irregular. Primeiramente, ele coloca o texto em português e a seguir o mesmo trecho em latim (em todas as passagens bilíngues anteriores, ele faz o contrário, mantendo a tradução portuguesa após o latim). Em alguns trechos, Mafra não menciona a passagem em latim, e em outros coloca a tradução portuguesa em discurso indireto (p. 179ss.). Por fim, na página 185, produz-se certo ruído ao colocar apenas um verso em latim no meio da citação da passagem em português da Eneida. Para quem não compreende a língua latina, isso atrapalha a compreensão do texto.

Em seguida, Mafra analisa a prosódia e a métrica da poesia latina e, após estes capítulos, faz uma seleção de passagens da Eneida, com o trecho em latim seguido da tradução em português.

O livro conta com esclarecedoras e detalhadas notas de rodapé sobre temas especializados. Ao final de cada capítulo, o autor relaciona uma bibliografia concisa e respeitável sobre cada tema discutido. Além 
disso, o livro possui inúmeras imagens de esculturas, fotografias e pinturas, que ilustram os tópicos. Embora a obra possua um caráter abrangente, Mafra também aprofunda alguns assuntos, ao tratar da prosódia e da métrica da poesia latina e ao analisar trechos de obras, sobretudo da Eneida. Visando especialmente a uma primeira compreensão da cultura clássica, o livro não deixa de ser também produtivo para pesquisadores da área de Estudos Clássicos. Cultura clássica grega e latina apresenta linguagem clara, despojada, que o torna agradável de ser lido, estimulando o leitor a aprofundar seus conhecimentos das obras clássicas greco-romanas. 